\title{
Relationship between Emotional Disturbance, Family Conflict, Social Pressure and Drug Craving Among Former Drug Addicts
}

\author{
Fauziah Ibrahim, Ezarina Zakaria, Norulhuda Sarnon, Salina Nen, Nazirah Hassan
}

\begin{abstract}
Research on drug cravings among former drug addicts is an important issue to be addressed in order to provide input to the government in an effort to prevent relapse among former drug addicts. This article aims to identify the relationship between emotional disturbance, family conflict, social pressure and drug cravings among former drug addicts. A survey study was conducted by using a cross sectional design. A total of 380 former addicts, who completed the rehabilitation program at the Cure and Care Rehabilitation Center (CCRC) and were undergoing a period of supervision by the National Anti-Drug Agency (AADK), were selected to participate in the survey study. The data were analyzed using an inferential statistic, the Pearson Correlation test. The results showed a moderate and positive significant relationship between drug cravings and emotional disturbance $(r$ $=.703, p<0.01)$, family conflict $(r=.540, p<0.01)$ and social pressure $(r=.606, p<0.01)$ among former addicts. These findings indicated that emotional disturbance, family conflict and social pressure that experienced by former addicts should be tackled by the stakeholders as it has a significant relationship with cravings, which may lead to relapse among former addicts.
\end{abstract}

Keywords: emotional disturbance, family conflict, social pressure, drug craving, drug addicts

\section{INTRODUCTION}

Drug relapse refers to the recurrence of pathological drug use after a period of abstinence. Strong desire for drugs could encourage former addicts returning to drug abuse [1]-[2]-[3]. A study conducted by Fauziah et al. found that craving for drug [F $(1,378)$ $=368.773, \mathrm{p}<.05)$ contributes 49.4 percent variance $\left(\mathrm{R}^{2}=.494\right)$ to emotional disturbance among former addicts under surveillance [4]. The findings show that craving for drug $(\beta=.703, p<.05)$ is the key indicator affecting emotional disturbance among former drug addicts, thus trigger relapse behaviour. Meanwhile, a qualitative study discovered that addicts having difficulties to quit thinking about drugs because drugs have changed the way a person's body works [5]. The study further found that former drug addicts always missing moments doing drugs with their acquaintances, though they have been abstinence for some period of time.

In Malaysia, the treatment and rehabilitation of drug relapse is very challenging [6]. Former addicts who received treatment and back to the society are exposed to surroundings that risky to relapse. Craving for drugs is major cause for many former addicts returning

\section{Revised Manuscript Received on September 25, 2019}

First Author name, Fauziah Ibrahim, School of Psychology and Human Development, Faculty of Social Science and Humanities, National University of Malaysia, 43600 Bangi, Selangor, MALAYSIA.

Second Author name, Ezarina Zakaria, School of Psychology and Human Development, Faculty of Social Science and Humanities, National University of Malaysia, 43600 Bangi, Selangor, MALAYSIA.

Third Author name, Norulhuda Sarnon, School of Psychology and Human Development, Faculty of Social Science and Humanities, National University of Malaysia, 43600 Bangi, Selangor, MALAYSIA to drug abuse. They subsequently seek solution for recuperating assistance to undergoing treatment and drug rehabilation programmes [7]. Based on statistics released by the National Anti-Drug Agency, it was found that the total number of recurring cases of drug rehabilitation in 2017 has increased from 7,482 to 7,793 addicts in 2018 [8]. The increased figures concerned many, not only surrounding communities but also challenges for stakeholders in managing and providing treatment to former drug addicts each year. High reconsumption of drug would also contributes to criminal activities in the society. A study conducted by Zainudin \& Norazmah found that drug intake may cause an individual to commit delinquencies and crime activities [9]. Meanwhile, a study conducted by Steven, Alex \& Trace discovered that most of the crime occured were caused by drug abuse problems [10]. The results of this study are parallel with one local study carried out by Fauziah et al. which found that 57.4 percent of street crime prisoners involved in their studies reported drug abused. They also reported street crime activities such as stealing, snatching and robbing without firearms [11]. Negative impacts on the society resulted by drug abuse problems is seen as major obstacle for the country in an effort to achieve the aspiration Vision 2020.

Emotional Disturbance: Emotions play an important role to separate an individual from drug cravings [12]. In this study, emotional disturbance refers to an agitation feelings such as anxiety, disappointment, lonely, sad, self-isolation and boredom encountered by former drug addicts that triggered craving for drugs. Without appropriate control, emotional disturbance could lead to relapse behaviour [13] and the desire to drug uses [14]-[15]. A research examined by James discovered that negative emotions such as depression and anxiety experienced by individuals play an important role towards the successfulness of the treatment and rehabilitation processes [16]. Individuals with negative emotions tend to relapse by taking alcohols and drugs. Further, a study conducted by other resercher found that the failure to manage emotions was the significant factor to former addicts returning to drug abuse [17]. This means that those who failed to control their negative emotions increase risk to return to drugs. To control drug craving, therefore the emotion of the addicts need to be managed appropriately.

Family Conflict: In this study, family conflict refers to the involvement of family members with drugs and the existence of misunderstanding between addicts and family members, thereby assembled an unharmonious relationships as well as could lead to longing for drugs. Several studies have showed consistent findings in relation to the dysfunction of family with the desire to return to drug abuse, which lead to relapse [18]. Family factors including parental psychopathology, conflicts in the family and relationship distance in family are the strongest predictors of drug addiction [19]. A study conducted by Fauziah et al. on 400 relapse addicts in Peninsular Malaysia found that the level of relapsing addiction from the interpersonal conflicts aspect among the addicts was from moderate $(68.5 \%)$ to a low

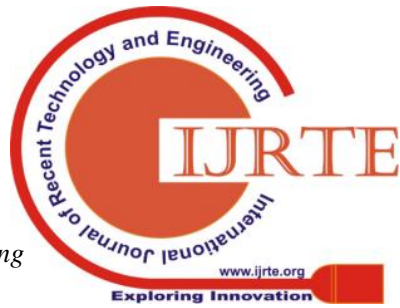


level of $17.7 \%$. Even though it indicated satisfactory from the aspect of client recovery, nonetheless there are $13.8 \%$ or a total of 55 relapse addicts were identify as having family conflicts. The conflicts that the addicts faced have to be addressed to prevent drug relapse [6]. A research carried out by McCarty et al. relates the negative pressure resulting from family conflicts and society especially peers during the abstinence period stimulating addicts to relapse [20]. Similarly a study conducted by Asbab, Zainal \& Hasnarul discovered that there was a positive and significant relationships between family support $(\mathrm{r}=.564, \mathrm{p}<.05)$ and the relapse tendency among addicts [21]. Whereas research conducted by Copello, Templeton \& Velleman found that social problems that occur in the community and constant family conflicts that is not being dealt with could cause opiate addicts to become addicts in a long period of time [22].

Social Pressure: In this study, social pressure refers to the situation or stressful condition that directly appear (living surroundings, working environment, drug addict co-worker) and indirectly (peers persuasion, being approached by drug dealer and drug being supplied by employers) that are capable to trigger drug cravings among former addicts. Samira, Haslinda \& Norbaya argue that the influence of uncontrollable social environments could contribute to the pressure in individuals and lead to relapse [23]. A study conducted by Clapp \& McDonnell found that pressure resulted from surroundings including peers and social media may trigger former addicts craving for drugs [24]. Meanwhile research done by Johnston, O'Malley \& Bachman discovered that surrounding factors play tremendous role in determining the recovery of addicts [25]. The diffiulties of former addicts to cope with the stressed surroundings with could lead them to drug cravings. Similar to this a study conducted by Asbah et al. discovered a significant relationship between social pressures and relapse tendency among addicts [21]. Where as a study conducted by Fauziah \& Naresh and Mahmud, Schottenfeld \& Chawarski argued that social factors have significant relationships with drug craving and relapse behavior. Indeed, these circumstances contributed to the increasing number of relapse addicts each year [26] -[27].

\section{RESEARCH OBJECTIVE}

This study was conducted to identify the relationship between emotional disturbance, family conflict and social pressure with drug cravings among former drug addicts.

\section{RESEARCH METHODOLOGY}

\section{Research Design}

This study used a quantitative cross-sectional approach. According to Malhota et al. a cross-sectional design is a method that involves data collection on one type of sample from a population at a specific point in time, based on the attribution of current respondents [28].

\section{Population, Sample and Location of Study}

In this research, the population of the study refers to the number of addicts that had undergone the Cure and Care Rehabilitation Centre (CCRC) programme and went through surveillance from external supervision. AADK reported 5,460 former addicts under surveillance in 2015 [29]. Participants selected in this study are multiracial. They had completed the CCRC treatment and rehabilitation, and were under the surveillance for a period of six months. Two sampling methods were used in this study. In the first stage, stratified random sampling was used to select Surveillance Centre by zone. Two AADK Surveillance Centre with the highest number of former addicts were selected to represent each zone. To meet this study purposes, nine AADK Surveillance Centre from four zones were selected as a sample (Table 1). Secondly, using systematic random sampling participants (former addicts) were selected from each zone.
Table 1: Research Location

\begin{tabular}{|l|l|l|}
\hline Bil & Zone & AADK Supervison Centre \\
\hline 1. & South Zone & AADK Johor and Negeri Sembilan \\
\hline 2. & East Zone & AADK Kelantan and Terengganu \\
\hline 3. & Central Zone & AADK Melaka and Selangor \\
\hline 4. & North Zone & AADK Penang and Kedah \\
\hline 5. & $\begin{array}{l}\text { Sabah / Sarawak } \\
\text { Zone }\end{array}$ & AADK Sarawak \\
\hline
\end{tabular}

In this study, the determination of the sample size was established based on the studied sampling that was developed by Cohen, Manion \& Morrison by taking into consideration the significance level at $\mathrm{p}<.05$ (significance level $=95 \%$ ) [30]. According to the sample size determination if the population for a study is 5,460 and the level of significance required is .05 . Therefore, the number of respondents required is 357 . In order to meet this study perseverance, researchers perceived that it is reasonable if the amount of the sample size provided is according to the sample size determination tabled by [30] i.e. 357 plus 380 people. It was intended to accommodate in the event of a dropout or errors in filing the survey form by respondents. Moreover, the larger the sample is, the study would be solid and would be able to reduce errors in the findings results. According to Mohd Najib enlarging the sample size would be able to elevate the validity and reliability of the scores of a particular study [31].

\section{Data analysis}

Data analyzation has been carried out by using Statistical Package for the Social Science for Windows (SPSS for Windows). The data were analyzed by using the inference analysis i.e. the correlation test that being used in this study to measure the relationship between emotional disturbance, family conflict and social pressure with drug cravings among former addicts. The interpretation of this correlation relationship was based on Guildford's (1973) Rule of Thumb ' as follows:

Table 2: Interpretation of correlation relationship based on Guildford's (1973) Rule of Thumb'

\begin{tabular}{|cl} 
Coefficient Pearson (r) & STRENGTH OF RELATIONSHIP \\
\hline$<.20$ & Almost no relationship \\
.20 to .40 & Weak correlation \\
.41 to .70 & Moderate correlation \\
.71 to .90 & Strong correlation \\
$>.90$ & Stronger correlation \\
\hline
\end{tabular}

The value of $\mathrm{r}$ indicates the strength of the relationship or the relation of two variables while the indication - or + indicates the direction of relationship of both variables. The higher the value of $r$, the stronger the relation of the variable which is interpreted as in Table 2.

The following are the instruments used in the research together with the value of reliability that has been carried out:

1. Emotional Disturbance Scale: 10 questions related to emotional disturbance among OKP. The reliability value for the scale used in this study was high at 0.893 .

2. Social Pressure Scale: 10 questions relating to social pressure among former addicts. The reliability value for the scale used in this study was high 0.2 .

3. Family Conflict Scale: 10 questions relating to family conflict among former addicts. The reliability value for the scale used in this study was high at 0.851 .

4. Drugs Relapse Scale: 10 questions related to drug cravings among former addicts. The reliability value for the scale used in this study was high at 0.943 . 
These questionnaires were developed by Fauziah et al. by using four-scale likert where options were arranged accordingly i.e (1) strongly disagree, (2) disagree, (3) agree and (4) strongly agree [32].

\section{Process of data Collection}

Before initiating the data collection, the research team acquired written permission from the National Anti-Drug Agency Director-General (AADK) to conduct research at the selected AADK Surveillance Centers in Malaysia. Upon the approval had obtained from AADK, researchers contacted the AADK Director of each center and arranged for an interview appointment to set the exact date to conduct the data collection. A set of questionnaire was distributed to all participants that randomly selected from each center. During data collection, researchers were assisted by the AADK Rehabilitation Officers to carry out the data collection process. Prior briefing was given to all counselors and officers involved in the data collection. Then, former addicts who under surveillance were recruited by the officers according to the required number by the researchers and would then segregated into two groups; literate former addicts and illiterate former addicts.

The purpose of dividing the groups is to facilitate the process of completing questionnaires among participants. For former addicts who were literate answered every questions on the questionnaire form that has been distributed to them and being supervised by AADK Recovery Officer and the research team. Meanwhile, for former addicts who were illiterate, an AADK rehabilitation officer was placed in the group of participants to assist in reading each questions provided for the purpose of facilitating the process of respondents answering the questions. Simultaneously, researchers would also monitor respondents as they answering the questionnaires for any query. To get the right number of answered questionnaire forms, the researchers checked each paper during the collection of the questionnaires. It aims to ensure the respondents fill up the questionnaire completely. Incomplete questionnaire, the research team will then return the paper to the particular participants and to ensure that he/she completed with the help of AADK Rehabilitation Officer.

\section{RESULT AND DISCUSSION}

The results of correlation tests among 400 former drug addicts to identify the relationship between emotional disturbance, family conflict and social pressure with drug relapse among them were conducted and obtained research results as in Table 3.

\section{$H_{1}$ : There is a significant relationship between emotional disturbance and drug craving among former drug addicts.}

The analysis of the study has found that emotional disturbance $(\mathrm{r}=$ $.703, \mathrm{p}<0.01$ ), shown positive, moderate and significant relationship with drug craving among former drug addicts. The significant level is less than .01. Thus, it can be concluded that emotional disturbance has a link with drug relapse. Positive relationship indicates that the higher rate of emotional disturbance increases drug craving that more likely to increase risk returning to drug abuse. Thus, the first hypothesis of the study $\left(\mathrm{H}_{1}\right)$ that predict the significant relationship between emotional disturbance and drug craving among former addicts accepted. These findings parallel with studies conducted by James and Cornelius that discovered negative emotion triggering relapse among drug addicts and alcoholics [16]-[14]. Raheleh et al. discovered that the failure in managing emotions is a significant factor on drug cravings among former drug addicts [17]. This means former addicts who failed to manage their negative emotions would increase the urge to return to drug abuse and relapse. Nonetheless, to deal with the drugs craving, the emotions of particular former addicts need to be well-managed and supported with effective guideline and strategy of action to deal with problems in life.
Table 3: Relationships between Emotional Disturbance, Family Conflict and Social Pressure with Drug Craving Among Former Drug Addicts $(n=400)$.

\begin{tabular}{|l|l|r|r|r|}
\hline Variable & & $\begin{array}{l}\text { Emotional } \\
\text { Disturbances }\end{array}$ & $\begin{array}{l}\text { Family } \\
\text { Conflicts }\end{array}$ & $\begin{array}{l}\text { Social } \\
\text { Pressures }\end{array}$ \\
\hline $\begin{array}{l}\text { Drug } \\
\text { Relaps }\end{array}$ & $\begin{array}{l}\text { Correlation } \\
\text { Value (r) }\end{array}$ & $.703^{* *}$ & $.540^{* *}$ & $.606 * *$ \\
\cline { 2 - 5 } & $\begin{array}{l}\text { Significance } \\
\text { Level (p) }\end{array}$ & .000 & .000 & .000 \\
\hline
\end{tabular}

Significance level $\alpha=0.01$ ( 2 end)

\section{$\mathrm{H}_{2}$ There is a significant relationship between family conflict and drug craving among former drug addicts}

Family conflict refers to the involvement of family members of former drug addicts and the existence of misunderstanding between addicts and family members, which would then create unharmonious relationships as well as would trigger drug craving. Based on the analysis, the findings discovered that family conflict $(r$ $=.540, \mathrm{p}<0.01)$ show a positive, moderate and significant relationship with drug craving. Positive relationship demonstrates that the higher the family conflict is, the higher the desire for former addicts to return to drugs. Many studies have shown consistent results on dysfunction of family institution influencing drugs relapse [18]. Therefore, based on the findings, the second hypothesis $\left(\mathrm{H}_{2}\right)$ which predicts a significant relationship between family conflict and drug craving among former addicts accepted. These findings parallel with McCarty that argue negative pressure resulting from family relationships, especially peers during abstinence periods that stimulating former addicts to drugs relapse [20]. Similarly, a study conducted by Asbab, Zainal \& Hasnarul has found that there is a positive and significant relationship between family support $(\mathrm{r}=$ $.564, \mathrm{p}<.05)$ with the tendency of relapse among former drug addicts [21].

\section{$\mathrm{H}_{3}$ There is a significant relationship between the social pressure} with drug craving among former drug addicts

Social pressure refers to the immediate situation or pressure condition that directly occurred (surroundings and living place, working environment, co-workers involved with drugs) and indirectly (peer persuasion, being approached by drug dealer and drug being supplied by employers) that would be able to trigger drug craving. Based on the analysis, it was found that social pressure $(\mathrm{r}=$ $.606, \mathrm{p}<0.01)$ shown the positive, moderate and significant relationship with drug craving. Positive relationship indicated that the higher the social pressure, the higher possibility to return to former addicts. Therefore, based on the results, this research accepted second hypothesis of the study (H3) that predict a significant relationship between family conflict and drug cravings among former addicts. The results of this study are in parallel with a study conducted by Samira, Haslinda \& Nobaya who found that the influence of uncontrolled social surroundings contribute pressure in the individuals and lead to relapse [23]. A study conducted by Clapp $\&$ McDonnell found that the pressures occur from the surroundings, including peer influences and social media, trigger former addicts returning to drug abuse [24]. While study conducted by Johnston, O'Malley \& Bachman found that surrounding factors play a critical role in determining the recovery of former drug addicts [25]. The social pressures that was being poorly managed could trigger the urge to return to drug abuse and subsequently relapse among former drug addicts.

Table 4 shows the findings of significant test of three established null hypotheses of the study. The results have found that the three alternative hypotheses are accepted $\left(\mathrm{H}_{1}, \mathrm{H}_{2}, \mathrm{H}_{3}\right)$. 
Table 4: Correlation Test Results of Null Hypotheses $(n=400)$

\begin{tabular}{|c|c|c|c|}
\hline Label & Hypothesis Null & $\begin{array}{r}\text { Analysis } \\
\text { Results }\end{array}$ & $\begin{array}{r}\text { Hypothesis } \\
\text { Decision }\end{array}$ \\
\hline $\mathrm{H}_{1}$ & $\begin{array}{l}\text { There is a significant } \\
\text { relationship between } \\
\text { emotional disturbance and } \\
\text { drug cravings among former } \\
\text { addicts }\end{array}$ & $\begin{array}{l}(\mathrm{r}=.703, \\
\mathrm{p}<0.01),\end{array}$ & Accepting $\mathrm{H}_{1}$ \\
\hline $\mathrm{H}_{2}$ & $\begin{array}{l}\text { There is a significant } \\
\text { relationship between family } \\
\text { conflict with drug craving } \\
\text { among former addicts }\end{array}$ & $\begin{array}{l}(\mathrm{r}=.540, \\
\mathrm{p}<0.01)\end{array}$ & Accepting $\mathrm{H}_{2}$ \\
\hline $\mathrm{H}_{3}$ & $\begin{array}{l}\text { There is a significant } \\
\text { relationship between social } \\
\text { pressure with drug craving } \\
\text { among former addicts }\end{array}$ & $\begin{array}{l}(\mathrm{r}=.606, \\
\mathrm{p}<0.01)\end{array}$ & Accepting $\mathrm{H}_{3}$ \\
\hline
\end{tabular}

\section{CONCLUSION AND SUGGESTION}

In conclusion, the study conducted on 380 former drug addicts discovered that emotional disturbance $(r=.703, p<0.01)$, family conflict $(\mathrm{r}=.540, \mathrm{p}<0.01)$ and social pressure $(\mathrm{r}=.606, \mathrm{p}<0.01)$ showed significant relationships with drug craving. The results of this study are consistent with previous studies. The analysis of the study argue that the craving for drugs was due to the presence of the relationship with the aspects such as emotional disturbance that experiencing by former drug addicts, conflict in the family and the existence of social pressures during recovery period. The findings also suggested that the urge to return to drugs among former addicts may occur due to factors associated with emotional disturbance, family conflict and social pressure. The higher level of the emotional disturbance, family conflict and social pressure encountered by former drug addicts, increase the desire to return back to drug abuse. This situation indeed could lead to relapse behavior. Therefore, this study suggests that the intervention modules for relapse addicts should emphasize on the aspects associated to these factors. In the modules, basic skills related to the aspects of emotional management, the strategies on dealing with family conflicts and stress management should be developed in order to improve the effectiveness of the treatment and rehabilitation process. The AADK officers and stakeholders should get involve in managing and treating former drug addicts by contributing in handling trainings related to relapse prevention modules. By this, the treatment and rehabilitation process to former addicts could be carried out effectively. The findings have shown positive implications in addressing problems that trigger drug craving and indirectly provide best strategies based on the empirical results of the study.

\section{ACKNOWLEDGMENT}

This research was supported by the National Anti-Drugs Agency (AADK), research code: SK-2016-008. Our appreciation also extended to Faculty of Social Sciences and Humanities, Universiti Kebangsaan Malaysia and to all who have participated in this study.

\section{REFERENCES}

1. Ekhtiari H. (2008). Cognitive and neural infrastructure of craving, assessment and intervention methods. J Addict. 3: 90-96.

2. Witkiewitz, K., Lustyk, M. B., \& Bowen, S. (2013). Retraining the addicted brain: A review of hypothesized neurobiological mechanisms of mindfulness-based relapse prevention. Psychology of Addictive Behaviors. 27(2):351-365.
3. Koob GF, Le Moal M. (2001). Drug addiction, dysregulation of reward and allostasis. Neuropsychopharmacology. 24(2):97-129

4. Fauziah Ibrahim, Ezarina Zakaria, Salina Nen, Norulhuda Sarnon \& Nazirah Hassan. (2018). Pengaruh Gangguan Emosi Dalam Kalangan Orang Kena Pengawasan. Jurnal Psikologi Malaysia, 32(4):159-171

5. Norazleen Mohamad Noor. (2015). Kerinduan dan ketagihan terhadap dadah: Punca belia kecundang dan kembali menagih. International Drug Prevention and Rehabilitation Conference (Prevent 2015). Selangor.

6. Fauziah Ibrahim, Bahaman Abu Samah, Mansor Abu Talib \& Mohamad Shatar Sabran. (2012). Penagih dadah dan keadaan berisiko tinggi kembali relaps. eBangi Jurnal Sains Sosial dan Kemanusiaan. 7(1):1-13.

7. Melemis S.M. (2015). Relapse prevention and the five rules of recovery. YALE Journal of Biology and Medicine, 88: 325-332.

8. Agensi Anti Dadah Kebangsaan (2019). Statistik Maklumat Dadah 2019. Kementerian Dalam Negeri, Selangor.

9. Zainudin Sharif \& Norazmah Mohamad Roslan. (2011). Faktor-faktor yang mempengaruhi remaja terlibat dalam masalah sosial di sekolah Tunas Bakti, Sungai Lereh, Melaka. Journal of Education Psychology \& Counseling 1(1):115-140.

10. Stevens, Alex and Trace, Mike and Bewley-Taylor, D. (2005) The Reduction of Drug-Related Crime: an overview of the global evidence. Project report. The Beckley Foundation, Oxford.

11. Fauziah Ibrahim, Ezarina Zakaria, Norulhuda Sarnon, Salina Nen, Suzana Mohd Hoesni, Khadijah Alavi, Nasrudin Subhi dan Mohd Suhaimi Mohamad. (2016). Meneroka Pendekatan Fenomenologikal Sosial Jenayah Jalanan dan Mekanisme Pencegahan Berasaskan Komuniti. Laporan Penyelidikan ERGS. UKM: Bangi.

12. Kassel, J. D. (Ed.). (2010). Substance abuse and emotion. Washington, DC, US: American Psychological Association.

13. Zywiak W.H, Stout R.L, Trefry W.B, Glasser I, Connors G.J, Maisto S.A, Westerberg V.S. (2006). J Subst Abuse Treat. 30(4):349-53.

14. Cornelius J.R, Maisto SA, Martin, CS, Bukstein OG, Salloum IM, Daley, DC, Wood DS, Clark DB. (2004). Major depression associated with earlier alcohol relapse in treated teens with alcohol use disorder. Addict Behav. 29:1035-1038.

15. Tiffany ST. Drug craving and affect. In: Kassel JD, (2010). Substance Abuse and Emotion. Washington DC: American Psychological Association; pp. 83-108.

16. James, R. McKay. (2012). Negative Mood, Craving and Alcohol Relapse: Can Treatment Interrupt the Process? Current Psychiatry Reports. 13(6): 431-433.

17. Raheleh Haghiaght, Nezamaddin Ghasemi, Mehdi Rabiei, Asghar Zerehposh, Ahmadreza Kiani. (2013). The Comparison of Attentional Bias and Difficulty of Emotional States Regulation and Their Correlation with Craving Severity in Drug Abuser Methamphetamines and Crack. Zahedan Journal of Research in Medical Sciences. 16(Suppl 1): 29-34

18. Fals-Stewart, W., \& Clinton-Sherrod, M. (2009). Treating intimate partner violence among substance-abusing dyads: The effects of couples therapy. Professional Psychology: Research and Practice, 40(3), 257-263

19. Tobler, A. L., \& Komro, K. A. (2010). Trajectories of parental monitoring and communication and effects on drug use among urban young adolescents. The Journal of Adolescent Health, 46(6): 560-568.

20. McCarty, D., Perrin, N. A., Green, C. A., Polen, M. R., Leo, M.C,\& Lynch, F. (2010). Methadone maintenance and the cost and utilization of health care among individuals dependent on opioids in a commercial health plan. Drug and alcohol dependence, 111(3): 235-240

21. Asbah Razali, Zainal Madon, Rumaya Juhari \& Hasnarul Khadi Abu Samah (2016). International Journal of Pharmacy \& Pharmaceutical Research. Vol. 7(4): 326-341.

22. Copello A.G, Templeton L, Velleman R. (2006). Family interventions for drug and alcohol misuse: is there a best practice? Curr Opin Psychiatry. 19(3):271-276

23. Samira G., Haslinda A., Nobaya A., Ali A. (2010). Enviromental Factors Influencing Relapse Behavior among Adolescent Opiate Users in Kerman (A Province in Iran). Global Journal of Human Social Science. 10(4): 71-76

24. Clapp J.D \& McDonnell A.L. (2000). The relationship of perceptions of alcohol promotion and peer drinking norms to alcohol problems

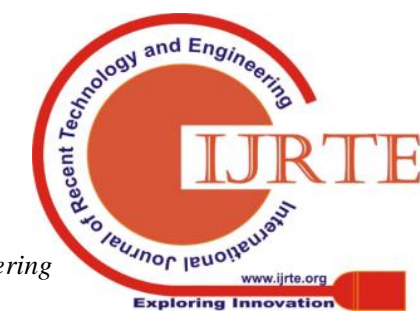


reported by college students. J Coll Stud Dev. 41:19-26.

25. Johnston, L.D, O’Malley, P.M Bachman, J.G. (2005). Monitoring the Future National Results on Adolescent Drug Use: Overview of Key Findings, Bethesda, MD: National Institute on Drug Abuse

26. Fauziah Ibrahim \& Naresh Kumar. (2009). Factors Effecting Drug Relapse in Malaysia: An Empirical Evidence. Asian Social Science, 5(12):37-44.

27. Mahmud Mazlan, Schottenfeld, R.S. \& Chawarski, M.C. (2006) New Challenges and Opportunities in Managing Substance Abuse in Malaysia. Drug and Alcohol Review, 25(5), 473-478.

28. Malhotra, N.K., Hall, J., Sham, M \& Crsip, M. 1996. Marketing Research: Applied Orientation (1st Edition). Sydney: Prentice Hall.

29. Agensi Anti Dadah Kebangsaan (2016). Statistik Maklumat Dadah 2016. Kementerian Dalam Negeri, Selangor.

30. Cohen, L., Manion, L. \& Morrison, K. (2001). Research Methods in Education (5th ed.). London: Routledge Falmer.

31. Mohd Najib Abdul Ghaffar. (1999). Kaedah Penyelidikan Pendidikan. Skudai: Penerbitan. Universiti Teknologi Malaysia. Edisi Kedua.

32. Fauziah Ibrahim, Ezarina Zakaria, Salina Nen, Norulhuda Sarnon \& Siti Mariam Mursidan. (2017). Kadar Kecenderungan Relaps dan Kejayaan Mengekalkan Kepulihan dalam Kalangan Penghuni yang Tamat Menjalani Rawatan dan Pemulihan di CCRC. Laporan Akhir Penyelidikan: UKM-AADK, Selangor

\section{AUTHORS PROFILE}

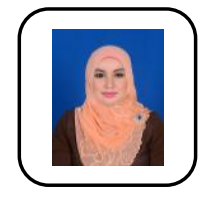

Fauziah Ibrahim (Ph.D)

Lecturer

School of Psychology and Human Development

Faculty of Social Science and Humanities,

National University of Malaysia

43600 Bangi, Selangor,

MALAYSIA.

Email: ifauziah@ukm.edu.my

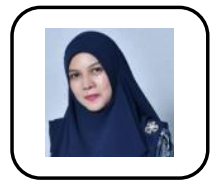

Ezarina Zakaria (Ph.D)

Lecturer

School of Psychology and Human Development,

Faculty of Social Science and Humanities,

National University of Malaysia,

43600 Bangi, Selangor,

MALAYSIA.

Email: ezaz@ukm.edu.my

Norul huda Sarnon (Ph.D)

Lecturer

School of Psychology and Human Development,

Faculty of Social Science and Humanities,

National University of Malaysia,

43600 Bangi, Selangor,

MALAYSIA.

Email: norul@ukm.edu.my

Salina Nen (Ph.D)

Lecturer

School of Psychology and Human Development,

Faculty of Social Science and Humanities,

National University of Malaysia,

43600 Bangi, Selangor,

MALAYSIA.

Email: salina@ukm.edu.my

\section{Nazirah Hassan (Ph.D)}

Lecturer

School of Psychology and Human Development,

Faculty of Social Science and Humanities,

National University of Malaysia,

43600 Bangi, Selangor, MALAYSIA.

Email: nazirah@ukm.edu.my 